\title{
The Struggle for Peace: \\ The Anglo-American Relations from the War of 1812 to the Monroe Doctrine (1812-1823)
}

\author{
N.V. Sang, L. Trang, P.N.H. Chinh, P.T.H. My, N.T.K. Tien, and N.T.H. Yen
}

\section{ABSTRACT}

The article aims to analyze Anglo-American relations' reconstruction from the end of the War of 1812 to the Monroe Doctrine declared in 1823. Based on this goal, the paper focuses on presenting Anglo-American relations related to American natives, negotiations to find solutions to border disputes and other issues; the re-building of trade relations interrupted by the War of 1812. The study applies sources such as monographs and treaties based on historical and logical methods. The results indicate three main issues to build peaceful relations between Great Britain and the United States in this period. First, overcoming the consequences of the War of 1812; Secondly, resolving disputes existing in relations between the two countries in the previous period; and lastly, developing trade relations between the two countries. The paper contributes to the study of AngloAmerican relations and issues of American history in the mentioned period.

Keywords: Great Britain, Fishing Right, Northeast Border, the War of 1812, Trade, US
Published Online: January 28, 2022

ISSN: $2736-5522$

DOI: 10.24018 / ejsocial.2022.2.1.208

N.V.Sang*

The University of Danang - University of Science and Education, Vietnam.

(e-mail: nvsang@ued.udn.vn)

L. Trang

The University of Danang - University of Science and Education, Danang, Vietnam.

(e-mail: 1trang ${ }^{\circledR}$ ued.udn.vn)

P.N.H. Chinh

The University of Danang - University of Science and Education, Vietnam.

(e-mail: huychinh0812az ${ }^{@}$ gmail.com) P.T.H. My

The University of Danang - University of Science and Education, Vietnam.

(e-mail: pthmy@ ued.udn.vn)

N.T.K. Tien

The University of Danang - University of Science and Education, Vietnam.

(e-mail: ntktien@ ${ }^{@}$ ued.udn.vn)

N.T.H. Yen

The University of Danang - University of Science and Education, Vietnam.

(e-mail: nth.yen ${ }^{\circledR}$ ued.udn.vn)

*Corresponding Author

\section{INTRODUCTION}

In 1812, the war between Great Britain and the United States broke out nearly 30 years after the end of the American Revolutionary War (Sang, 2021). This war had its origins in conflicts in Anglo-American relations involving neutral commercial rights, impressment of American sailors, the Chesapeake-Leopard affair and American natives' problem After two years of war, both countries realized that it was unnecessary to prolong the war and sought a negotiated solution. The Treaty of Ghent signed in 1814 ended the war and established peace in the British-American relations. In fact, the Treaty did not address issues related to economic interests in maritime, trade and border disputes between Great Britain and the US (Sang, 2018). After the War of 1812, many problems still existed in Anglo-American relations, in which the consequences of the war were the most noticeable. Therefore, both Great Britain and the US in this period made great efforts in solving problems caused by the War of 1812 and the conflicting issues in the Anglo-American relationship related to the previous stages, ensuring the interests of both two countries from this relationship.

\section{RESULTS AND DISSCUSSION}

A. Diplomatic efforts to resolve the results of the British-American relations related to the War of 1812

The 1812 war helped the Americans assert that the alliance of Indian and British tribes formed during the 1812 war played an important role for Great Britain but a direct threat to United States security in Northwest boundary. Therefore, during the negotiation of the Treaty at Ghent in 1814, Great Britain made 
a request to maintain allies with the Indian as an essential condition for inclusion in the Treaty. At the same time, the Great Britain proposed that an Indian - American boundary should be established based on the Greenville Treaty. Americans refused to accept the above terms. At this time, Great Britain was tired of war and had to pay attention to events in Europe around Napoleon's failure. In addition, the financial difficulties led the British government to escape the war with the Americans. As a result, Great Britain supported the boundary issue and accepted to restore Indian tribes to their situation before the 1812 war (Calloway, 1986). Article IX of the Ghent Treaty in 1814 committed to restore the Indians' assets, rights and privileges in 1811, and committed to end the Indians' hostilities against Britain and the United States (Yale Law School, 2021).

When peace was restored, the Indian loyalty became an American concern. Springwells Treaty was signed with about 20 agreements between United States representatives including William Henry Harrison, Duncan McArthur, John Graham and a series of Indian tribes of Wyandot, Delaware, Seneca, Shawnee, Miami, Chippewa Ottawa and Potawatomi Aboriginal people. The Treaty was signed on September 8th, 1815, near Detroit, Michigan (Schultz et al., 2000), (Daszynska, 2018). The goal of the Treaty was to separate the Indian-British alliance formed during the 1812 war and ensured their future loyalty to the United States. The Treaty formally terminated all hostilities between the United States and the Indians and restored Indians all their properties, rights, and privileges since 1811, and reaffirmed the content of the Greenville Treaty in 1795 and 1814. In contrast, Indians agreed to place themselves under the protection of the United States Government and refused any links with the Great Britain (Ricky, 1999). The Treaty also prevented Great Britain from exchanging trade with Indians which led to a breakup of the British and Indian alliances. Because Americans supposed that the existence of this alliance threatened America's security. Despite being prevented, in fact, smuggling between the British and Indians in the border area still took place (Pastusiak, 1997).

After the war, the United States and Great Britain had significant naval forces in the northern lakes of the United States. In that context, on February 17, 1815, a Resolution on the reduction of the Great Lakes Fleet was discussed and passed by the United States House of Representatives a day later. In the late summer of 1815, United States Secretary of State John Quincy Adams announced that instead of disarming the Fleet on the lakes, Britain was planning to increase its scale and effectiveness (Boutell, 1901). British action caused the United States government to react. Immediately, President James Madison commissioned United States Secretary of State James Monroe to negotiate an agreement to prevent rising tensions and unnecessary costs that would develop if an arms race continued after the 1812 war (Radojewski, 2017). On November 16, 1815, Monroe wrote to Adams to instruct him to propose a mutual disarmament in the Great Lakes to British Government to avoid conflict and tension between the two countries. On January 25, 1816, Adams's offer was sent to British Foreign Secretary Lord Castlereagh. Adams discussed this issue with Castlereagh but after six months of negotiations the two sides almost failed to achieve any result.

By July 1816, British Secretary to the United States, Charles Honot had received instructions from British Government to conduct negotiations between the two countries involved in reducing the naval forces in the Great Lakes. British Government realized that maintaining the navy on the Great Lakes was not beneficial to them. However, British colony, in particular Canada, said that the withdrawal of British troops would make Canada get difficulties, especially under the direct pressure from the United States (Pastusiak, 1997). In order to solve the withdrawal of the troops in the Great Lakes, the British side sent a special envoy to Charles Bagot to negotiate with James Monroe. Bagot supposed that British Government was being willing to reach an agreement with the United States on this issue. While the United States also had a similar position and gave specific contents on the terms of the agreement between the two parties. The content of these terms was proposed by Monroe in a letter to Bagot on August 2, 1816. When Monroe became President in 1817, the negotiations were conducted between Bagot and Richard Rush (Boutell, 1901).

At first, Bagot focused on solving the issue of fishing rights, but the British Government supposed that the problem of naval restrictions in the Great Lakes meant more. To sign this Treaty, the two countries adopted a method of exchanging memos. On April 28, 1817, Bagot sent a treaty agreement to Rush. A day later, Rush sent Bagot a copy with such content. The Anglo-American Treaty signed through the exchange notes between Bagot represented the British Government and the Rush represented the United States Government which was also known as the Bagot-Rush Treaty. Almost a year later, it was signed on April 16th, 1818, the Treaty was submitted and ratified by the Senate. On April 28, 1818, the official Treaty was declared by the President of the United States (Daszynska, 2018).

The Treaty included three basic contents: 1) Both countries agreed that the naval force maintained on American lakes from now on would be limited by the number of vessels allowed by each party; 2) Each country was allowed no more than one vessel on Lake Ontario, two on Upper Lakes, one on Waters of Lake Champlain. Each vessel was limited to a maximum weight of 100 tons and an 18-pound cannon; 3) All other vessels equipped with weapons were immediately dismantled. No warship would be built or armed here (Bevans, 1968).

The Rush-Bagot Treaty was considered to have ended the Anglo-American naval race and seen as a 
diplomatic source of friendly international borders (The Canadian Encyclopedia, 2021). Without an agreement to disarm the lakes in April 1817, the naval arms race that began during the 1812 war would continue with both countries building a very large number of vessels (Radojewski, 2017). This Agreement immediately took effect when exchanging notes. The work of dismantling armed fleets on the lakes was quickly started. For a short time, the victory vessels of Perry and McDonough were abandoned or converted for peaceful commercial purposes (Boutell, 1901).

\section{B. Searching for solutions to resolve the disputed problems in the British-American relations}

Following the success of the Rush-Bagot Treaty, the Convention of 1818 between the United States and Great Britain was an important event that contributed to the improvement of the relationship between the two countries after the war (Yale Law School, 2021). Formal negotiations between the United States and Great Britain were held in England on August 27, 1818. The United States side included Albert Gallatin, United States Ambassador to France and Richard Rush, Minister of the United States to London. British forces participated in negotiations including Frederick John Robinson, Treasurer of the Royal Navy and Henry Goulburn, an undersecretary of state. After the negotiation process, the Treaty was signed in London on October 20, 1818, approved by England on 2nd November 1818 and declared by the President of the United States on January 30, 1819.

The Treaty consisted of 6 articles in which Article III was particularly extended by the Convention of 1827. The content of the Treaty was agreed by the two countries on several issues related to the issues of fishing rights, trade, borders, and slaves (Yale Law School, 2021). Article I of the Treaty regulated the United States rights on fisheries (Sang, 2021). Article II of the Treaty defined the Northeast border between the United States and the territory Canada belonging to Great Britain which, due to the dispute, had not been correctly determined by the two countries. The reason was that the geographical omission of the map was used in negotiations between the British and United States delegations in the Paris Treaty of 1783 (Yale Law School, 2021), (Mooroe, 1898). Under the provisions of this clause, the border between the United States and Canada was determined from the Southwestern point of Woods Lakes to the Stony Mountains (today the Rocky Mountains):

"A Line drawn from the most Northwestern Point of the Lake of the Woods, along the forty Ninth Parallel of North Latitude [...] and that the said Line shall form the Northern Boundary of the said Territories of the United States, and the Southern Boundary of the Territories of His Britannic Majesty, from the Lake of the Woods to the Stony Mountains" (Yale Law School, 2021).

After the term was signed, the border continued to dispute in subsequent periods and was only long-term determined through the Washington Treaty in 1842.

On the Northwestern border of the United States, Oregon was of particular interest to both countries. The negotiators of both sides affirmed that they did not reach an agreement on the establishment of Oregon's border, so they suspended the issue. Article III of the Convention of 1818 stipulated that the two sides would agree to set this area within 10 years free and open for both travelling and trading. Great Britain and the United States announced co-ownership of this land. This form had been determined by the two countries to contribute to reducing stress and differences in bilateral relations (Yale Law School, 2021). However, in 1827, due to the lack of a unified solution for the ownership of Oregon, the two countries continued to claim the co-ownership to this land. In fact, the benefits from Oregon were becoming increasingly attractive to traders of the two countries, especially fur. Oregon became the concern of the two countries. As a result, the Oregon problem would be an important factor in Anglo-American relations at the next stage (Sang, 2017), (Sang, 2018).

After the 1812 war, a new issue emerged in Anglo-American relation related to fisheries (Mc Grath, 1906). In fact, under the Paris Treaty of 1783, Great Britain recognized the United States' fishing right in Newfoundland and Gulf of Lawrence, Nova Scotia, the Magdalen Islands and Labrador like the rights they enjoyed during colonial times (Yale Law School, 2021). During the negotiation of the Treaty at Ghent in 1814, both British and American negotiators failed to agree on the rights of fisheries and maritime on Mississippi river, particularly the fishing right of Americans on the British territorial waters. However, both delegations wanted to establish peace soon, so they agreed not to mention this issue in the Ghent Treaty (Balch, 1909). From 1815, Great Britain defied the 3rd provision of the 1783 Treaty which granted American fishermen the right of fisheries in British waters. British arrested many American vessels caught in British waters. On June 9, 1815, a British vessel warned American fishing vessels in open waters 45 miles away from Cape Sable (Balch, 1909). These arrests had partly prevented the fishing rights of American fishermen which made their relationship worse. In the following months, American fishing rights, especially on British territorial waters, became the subject of discussion between John Quincy Adams, the Minister of the United States in England and Lord Bathurst, Secretary of State and Lord Castlereagh Barthurst's successor. The two sides also discussed about Article III of the 1783 Treaty which was still valid or terminated by war (Balch, 1909).

At the same time with diplomatic activities, Britain also wanted to adopt ship arrest activities to cause 
pressure the United States to reach a peace agreement involving sea fishing rights. In June 1817, England caught between twenty American fishing vessels off Nova Scotia and took them to the Port of Halifax. The United States objected to the arrest of fishermen and said that these ships only sought for settle due to bad weather and fresh water supplies (Pastusiak, 1997). To avoid ongoing conflicts, Great Britain, and the United States at the Conference on October 20,1818, negotiated fisheries based on the principle of mutual concessions.

Article I of the Convention of 1818 defined the fishing right of the United States. The two countries agreed that American citizens kept the permanent right for fisheries in the Southern Coast of Newfoundland, Western and Northern Coast of Newfoundland, the Coasts, Bays, Harbors, and Creeks, the Southern Coast of Labrador. The American vessels kept the right to visit British ports and bays in North America for shelter, repairing, wood and water supply and not for other purposes (Yale Law School, 2021). Compared to Article III of the Treaty of Paris in 1783 and Article I of the Convention of 1818, the American fishing right in the region was almost unchanged. However, the fishing right of American fishermen in the British territorial waters under the Convention of 1818 was greatly restricted from the Treaty of 1783 (The Canadian Encyclopedia, 2021). On June 14, 1819, the British Parliament passed a act to accept Article I of the Convention of 1818 that allowed Americans to fish in Newfoundland. As agreed on American fishing right, the happenings in the sea did not go smoothly. Great Britain continued to arrest American fishing vessels. Therefore, since 1822, two Anglo-American countries continued discussing to seek for solutions to this issue.

\section{Trade re-establishment in the British-American relations}

Among the issues of Anglo-American relations, one of the first tasks of the United States Government was to restore trade relations which were interrupted by Napoleon's wars. In fact, the war made all United States trade treaties ineffective and forced to recover (Green, 2009). The British West Indies were an attractive market for the United States but remained close due to the war of 1812. After the war, the United States sought all possible ways to re-enter this market.

Since 1815, Great Britain regulated only a list of United States products to be exported to British colonies in Western Indies and North America and must be exclusively shipped by British vessels. Only the case of St. George and Hamilton on Bermuda was the exception. In the summer of 1816, Adams tried to convince Castlereagh about the necessity to relax British restrictions on American products. According to Adams, these regulations hurted the United States benefits on sea transportation. Adams explained that all countries had considered accepting United States vessels fairly with British ones in transporting goods to British colonies. However, Castlereagh insisted that the permission of foreigners for trading with British colonies in the West Indies and in North America was a privilege (Yale Law School, 2021). In August 1816, Castlereagh informed Adams; the British Government respected the colony and refused to participate in any trade-related negotiations between the United States and the West Indies. Thus, those attempts to reach a commercial agreement in the British West Indies by diplomatic means in 1816 failed (Benns, 1923).

Failure to seek for a diplomatic solution in trade in British West Indies and British North America colonies, on March 1, 1817, the United States Congress passed Navigation Act restricted imports of British West India products to United States vessels and ships owned by colonial traders. However, it did not prohibit the export of United States goods to British islands. The Act also stated that all goods transported among United States ports must only be shipped in vessels entirely owned by United States citizens or belonging to West Indian merchants. The tonnage tax for vessels licensed to trade along the coast was set at six cents per ton for American-managed vessels and fifty cents for other vessels . In 1817 the American commercial revenge campaign began.

The Great Britain quickly responded to this act. On March 18, 1817, before the United States Secretary received information on the adoption of the maritime law, Castlereagh informed him that the British Government had received the information and considered it completely because it was not the cause of any complaints and dissatisfaction. At the same time, Castlereagh informed Adams that the British Government was ready to make concessions to the United States in British colonial trade exchanges. After that, Castlereagh sent Adams a draft with four articles on the expansion of United States vessels for commercial purpose and other purposes (Benns, 1923).

The United States Government finally gave a public solution to the British colonial system that began the era of maritime commercial disputes. On September 30th, 1818, the United States closed ports for British vessels from the colony. The Maritime Act of 1818 came into operation that led to the end of the commercial Convention in 1815. Therefore, the two countries needed to reconnect negotiations in respect of common trade. The United States had taken the case as a chance to expand trade between the United States and British colonies in Western India and North America. From the facts, Adams believed that the British Government would participate in negotiations and achieve a trade treaty (Benns, 1923). Britain also wanted to accept the United States offer as a basis for negotiations related to the West Indies. However, the two countries did not reach an agreement on this issue. 
From British policies and the United States maritime acts, trade between the United States and the British West Indies was affected. American goods to British West Indies had to transport in many different forms. In addition to the direct form, the goods were also transported to the British North America colonies and the Swedish and Danish West Indies then to the British West Indies. Exports of United States goods to the West Indies through these forms were achieved in 1818 and 1819 as shown in the table below.

TABLE I: EXPORT VALUE OF THE UNITED STATES TO THE BRITISH WEST INDIES IN 1818 AND 1819 (IN DOLLARS)

\begin{tabular}{lccc}
\hline \hline & For years ending September 30 & 1818 & 1819 \\
\hline 1 & British West Indies, including Bermuda & $3,488,653$ & 843,312 \\
2 & British North American Provinces & $2,355,700$ & $3,038,995$ \\
3 & Swedish West Indies & 278,846 & 345,793 \\
4 & Danish West Indies & 983,583 & $1,120,857$ \\
\hline & Total & $7,106,782$ & $5,348,957$ \\
\hline \hline
\end{tabular}

On May 15, 1820, the United States Congress continued to strengthen trade restrictions with Britain. As a rule, United States ports would close after the date on September 30th, 1820. This went against British vessels from ports in Lower Canada, New Brunswick, Newfoundland, and St. Louis John or Cape Breton, Bermuda, the Bahama Islands, the Caicos Islands, or any British port in the West Indies. The Act also had impacts on export and import prices in the British West Indies. Import prices on these islands increased by double in shipping charge, insurance, and ship tax fees. British plantation owners were forced to accept this increase in price because they needed American goods. Moreover, one negative impact on British plantation owners in the West Indies was the request to use money for exchange rather than bartering. On the US side, restricting trade with the West Indies affected the states of Maryland, Virginia, Georgia, North and South Carolina, Norfolk. Norfolk's exports fell from \$2.699.111 in 1818 to 298,684 dollars in 1821. Therefore, these states raised their opposition and required the elimination of restrictions (Pastusiak, 1997).

In March 1822, the United States proposed open the ports for British vessels from the West Indies for trade and business. A few months later the British relaxed their restrictions on American vessels. On July 24th, 1822, the West Indian and American Trade Bill were approved by the British Government. Under the provisions of this Law, goods could be imported from any foreign country on the North or South America continent or from any foreign island in the West Indies shipped directly by British vessels or their vessels to the West Indies and North America (Benns, 1923). In response to British concessions, on August 24, 1822, Monroe announced that he would allow British vessels from the West Indies to arrive at the port of the United States. On March 1st, 1823, the United States abolished the difference in customs fees between the United States vessels and British vessels. The importance of mutual reciprocal trade in exchanges between the United States and the British West Indies and the North British colonies was eased by both sides. However, in 1830, restrictions on trade between the two countries were officially removed.

\section{CONCLUSION}

After the war, by the Anglo-American peaceful method, Great Britain and the United States reestablished the relationship by using the methods of Treaties and Arbitration. The issues of naval disarmament in the Great Lakes, the issue of ensuring Indian loyalty, the issue of fisheries and the Northeastern borders were resolved by the two countries. A period of peace in bilateral relations came. However, despite all peaceful solutions to the above-mentioned issues, many issues were only temporary agreements which did not reach agreement between the two countries, thus it continued to be the source of disputes between Anglo-American in the next phase, especially disputes in respect to the border issues and trade at sea.

\section{ACKNOWLEDGMENT}

This research is funded by Funds for Science and Technology Development of the University of Danang under project number B2021-DN03-03.

\section{CONFLICT OF INTEREST}

Authors declare that they do not have any conflict of interest. 


\section{REFERENCES}

Balch, T. W. (1909). The American-British Atlantic Fisheries Question. Proceedings of the American Philosophical Society, 48(193), 322-323.

Benns, F. L. (1923). The American Struggle for the British West India Carrying-Trade 1815-1830. Indiana: Indiana University.

Bevans, C. I. (1968). Treaties and other International Agreements of the United States of America, Vol. 13: 1776-1949. New York: U.S. Department of State.

Boutell, H. S. (1901). Is the Rush-Bagot Convention Immortal? The North American Review, 173(538), 331-348.

Calloway, C. G. (1986). The End of an Era: British-Indian Relations in the Great Lakes Region after the War of 1812. Michigan Historical Review, 12(2), 1-20.

Daszynska, J. (2018). Crisis and Compromise in the Founding Fathers of the United States. Lodz: University of Lodz.

Green, J. M. (2009). Relations between United States and Great Britain, 1776-1915. Michigan: University of Michigan Library.

Mc Grath, P. T. (1906). The Newfoundland Fishery Dispute. The North American Review, 183(604), 1134-1135.

Mooroe, J. B. (1898). History and Digest of the International Arbitrations to which the US has been a party. New York: Government Printing Office.

Pastusiak, L. (1997). Diplomacy of the United States in the XVIII and XIX centuries. Warsaw: Adam Marszałek.

Radojewski, C. M. (2017). The Rush-Bagot Agreement: Canada-US Relation Transition. American Review of Canadian Studies, 47(3), 280-299.

Ricky, D. B. (1999). Encyclopedia of Massachusetts Indians. New York: Native American Books Distributor.

Sang, N. V. (2017). The Question of Oregon in British-American relations, 1818-1846. Kolo Historii, 21, 43-58.

Sang, N. V. (2018). The British-American Diplomacy in Searching for the Northeast Boundary in Maine and New Brunswick, 18201846. Annals of the University of Craiova. History, 2(34), 35-48.

Sang, N. V. (2021). The British-American Relations from the Monroe Doctrine to American-Mexcan War (1823-1846) [Quan hệAnhMỹ tù học thuyết Monroe đến chiến tranh Mỹ-Mexico, (1823-1846)]. Hanoi: The gioi Publisher.

Schultz, D. J., Haynle, K. N., McCulloch, M. A., \& Aoki, A. L. (2000). Encyclopedia of Minorities in American Politics: Hispanic Americans and Native Americans, Vol. 2: Hispanic Americans and Native Americans. New York: Greenwood.
Canadian
Encyclopedia
(2021,
December
30). Convention

of

1818.

The Canadian Encyclopedia (2021, December 30). Rush-Bagot Agreement. https://www.thecanadianencyclopedia.ca/en/article/rushbagot-agreement.

Yale Law School (2021, December 30). Convention of 1818 between the United States and Great Britain. http://avalon.law.yale.edu/19th_century/conv1818.asp.

Yale Law School (2021, December 30). A Convention to Regulate the Commerce between the Territories of the United States and of His Britannica Majesty. http://avalon.law.yale.edu/19th_century/conv1816.asp.

Yale Law School (2021, December 30). The Paris Peace Treaty of September 30, 1783. http://avalon.law.yale.edu/18th_century/paris.asp.

Yale Law School (2021, December 30). Treaty of Peace and Amity between His Britannic Majesty and the United States of America. http://avalon.law.yale.edu/19th_century/ghent.asp. 


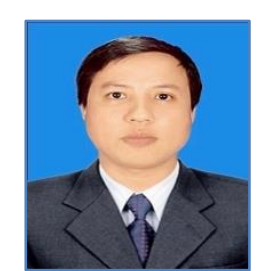

N.V. Sang earned his PhD degree in History from Institute of History, Faculty of Philosophy and History, University of Lodz, Poland. He is currently working as a Deputy Head of Department of Scientific Affairs and International Cooperation, University of Science and Education, The University of Danang, Vietnam. His current research focuses on American History in the XVII - XIX centuries, British-American relations from the American Revolutionary War to Civil War, Founding Fathers of the United States, American Constitution. He has authored several articles in prestigious journals in Vietnam and in international journals indexed by Scopus. Nguyen Van Sang is the corresponding author and can be contacted at: nvsang @ ued.udn.vn.
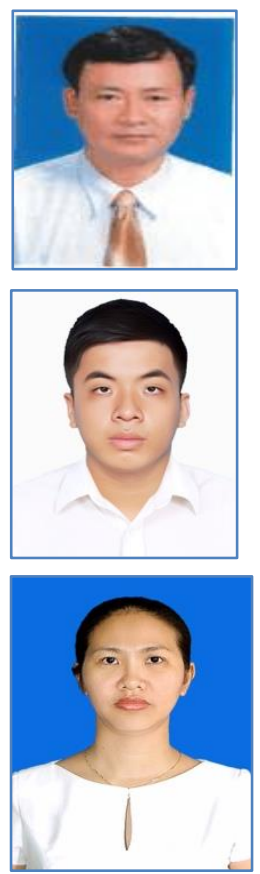

L. Trang is Associate Professor in History. He is a Rector of University of Science and Education, The University of Danang, Vietnam. He obtained his PhD degree from Ha Noi National University of Education, Vietnam. Luu Trang has accomplished important tasks in conducting projects, publishing books and articles, teaching students and creating new knowledge. He is a leading specialist in History at University of Science and Education, The University of Danang as well as Central Vietnam.

P.N.H. Chinh graduated from Faculty of History, University of Science and Education, The University of Danang, Vietnam, with a bachelor's degree in History. Currently, he is applying for his master's in International Relations. His research focuses on American Diplomacy, US-China Trade War, Vietnam - ASEAN relations during the XXI century, Modern China History. He has several articles publishing on Vietnamese journals in related topics.

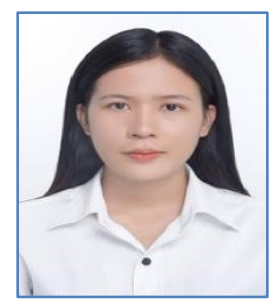

P.T.H. My obtained her bachelor's degree in English Studies in University of Foreign Language Studies, The University of Danang, Vietnam. She is currently working at Department of Scientific Affairs and International Cooperation, University of Science and Education, The University of Danang, Vietnam. Her current research interests include American Culture, American History.

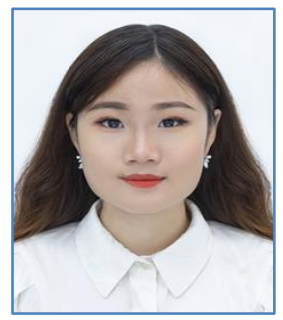

N.T.H. Yen earned her Master's degree in International Relations at VNU University of Social Sciences and Humanities, Vietnam. She is working as a lecturer in International Relations at University of Science and Education, The University of Danang, Vietnam. Her research is History of International relations, VietnamEU relations, Political Consitution. She has also published several articles in Vietnamese journals. 